\title{
horticultura
brasileira
}

MARCUZZO LL; CARVALHO J. 2014. Production and resistance of three scallion cultivars to pink root. Horticultura Brasileira 32: 363-366. DOI - http:// dx.doi.org/10.1590/S0102-05362014000300020

\section{Production and resistance of three scallion cultivars to pink root}

\author{
Leandro L Marcuzzo; Jaqueline Carvalho
}

Instituto Federal Catarinense, C. Postal 441, 89163-356 Rio do Sul-SC; marcuzzo@ifc-riodosul.edu.br; jaquelinecarvalho1991@hotmail.com

\begin{abstract}
The production of scallion has been widely exploited on small farms, since it requires little care and is largely commercialized close to the production sites. Pink root, caused by Phoma terrestris (syn. Pyrenochaeta terrestris), is among the main diseases affecting this crop. However, little information on aspects related to yield and few cultivars resistant to the disease are available. In this study we evaluated these variables on Konatsu, Natsu and Nebuka cultivars. The experiment was carried out in Lontras, Santa Catarina state, Brazil, in a complete randomized blocks design with four replications. After 80 days of transplantation the following parameters were evaluated: plant mass, total and marketable number of leaves, total and marketable mass of leaves, lenght and weight of roots. The total number of bunches was assessed as an evaluation aiming the market. The disease severity, in percentage on the root system, was assessed for the pink root. The average values of the variables were subjected to analysis of variance by $\mathrm{F}$ test and mean comparison test by Tukey, $5 \%$. The Konatsu cultivar presented higher average mass per plant $\left(159\right.$ g plant $\left.^{-1}\right)$ compared to Nebuka and Natsu cultivars. The average mass of marketable leaves for 'Konatsu' was $56.17 \%$ higher than for 'Nebuka'. The number of bunches produced by 'Konatsu' was $48 \%$ higher than for 'Nebuka'. The cultivar Konatsu was, therefore, more productive and resistant to the pink root disease.
\end{abstract}

Keywords: Allium fistulosum, Phoma terrestris, yield, genotypes.

\section{RESUMO}

Produção e resistência à raiz rosada em três cultivares de cebolinha-verde

A produção de cebolinha-verde tem sido muito explorada em pequenas propriedades, já que exige poucos cuidados e grande parte é comercializada próxima aos locais de produção. Entre as principais doenças da cultura, está a raiz rosada causada por Phoma terrestris (sin. Pyrenochaeta terrestris). No entanto, poucas são as informações sobre características de produção e resistência de cultivares a essa doença. O objetivo deste trabalho foi avaliar essas variáveis nas cultivares Konatsu, Natsu e Nebuka. O experimento foi instalado em Lontras-SC, em delineamento experimental de blocos casualizados com quatro repetições. Após 80 dias do transplantio foram avaliados a biomassa das plantas, o número total e comercial de folhas, a biomassa de folhas totais e comerciais, o comprimento de folhas, e o comprimento e biomassa de raízes. Para a análise comercial foi determinado o número total de maços. Para a raiz rosada foi avaliado o percentual de severidade da doença no sistema radicular. As médias das variáveis foram submetidas à análise de variância pelo teste $\mathrm{F}$ e a comparação de médias foi realizada pelo teste de Tukey a 5\% de probabilidade. A cultivar Konatsu apresentou maior biomassa da planta $\left(159 \mathrm{~g} \mathrm{planta}^{-1}\right)$ em relação à Natsu $\left(89,5 \mathrm{~g} \mathrm{planta}^{-1}\right)$ e Nebuka $\left(72,75\right.$ g planta $\left.^{-1}\right)$. A biomassa de folhas comerciais da cultivar Konatsu foi 56,17\% maior que da cultivar Nebuka. O número de maços produzidos por Konatsu foi $48 \%$ maior ao da cv. Nebuka. A cultivar Konatsu foi mais produtiva e resistente à doença.

Palavras-chave: Allium fistulosum, Phoma terrestris, produtividade, genótipos.

(Recebido para publicação em 17 de outubro de 2013; aceito em 5 de junho de 2014) (Received on October 17, 2013; accepted on June 5, 2014)

$\mathrm{T}$ he production of condiments is an important source of income and sustainability for small farms. The scallion, also known as spring onion, is one of the condiments which is in high demand by consumers, either in raw, in natura, or processed. Due to high industry demand, its cultivation is being done on a larger scale. The fresh fruit market is done in fairs and supermarkets (Ferreira et al., 1993). According to Ferreira \& Casimiro (2011), the scallion is an important crop that contributes to the life quality of farmers, since its high added value and the family labor involvement provides a condition for sustainability on the farm.

The scallion (Allium fistulosum) is the predominant species for cultivation in Brazil and it adapts to various types of soil and to a wide range of temperatures, mild or cold. It can be grown throughout the year in highlands regions and during autumn-winter in lower regions. It is a perennial plant which presents cylindrical and fistulous leaves, 0.30 to $0.50 \mathrm{~m}$ height, produces small and tapered bulbs, wrapped in a pink film, with tillering and clump formation (Filgueira, 2007).
In Brazil, the most used cultivar is "Todo Ano", which presents as a characteristic the light green color. However, Japanese cultivars, like "Nebuka", "Evergreen", "Natsu Hosonegui" which are intense green, are also used (Cotia, 1987; Makishima, 1993; Filgueira, 2007). In Santa Catarina, in spring/summer crops, it has been recommended to grow the cultivar Futonegui and in autumn/winter the cultivars "Todo o Ano", Nebuka, Hosonegui and Ibirité (Silva \& Della Bruna, 2009).

The production of the scallion "Todo 
Ano" was evaluated by Heredia et al. (2003), and they concluded that the production of fresh biomass without the roots was of $7.95 \mathrm{t} \mathrm{ha}^{-1}$ and the average height was $33.21 \mathrm{~cm}$ per plant. Heredia $\&$ Vieira (2004) verified the production of 28,773.6 bunches ha-1 in cultivar "Todo Ano."

The scallion crop has shown a frequent disease in its root system, called the pink root, caused by Phoma terrestris (sin. Pyrenochaeta terrestris). This disease is widespread in countries where alliaceous are grown and resulting damages intensified by the fact that they fit the permanent cultivation succeeding annual cycles in the same area. In Brazil, the first occurrence of pink root was reported by Chaves \& Erickson, in 1960, on onion crops in the state of Minas Gerais (Wordell Filho \& Boff, 2006). Although Phoma terrestris is a low specific pathogen found in soil where alliaceous are grown, its occurrence intensifies in hot regions, where the continuous cultivation of this crop and the conventional management are adopted (Lenz, 2005).

The increase in consumer demand for scallion has stimulated the search for new varieties that respond to highest yields. However, the growing in Santa Catarina weather conditions can present distinct production and commercial characteristics, resistance reaction to pink root not corresponding to what was reported in the environment where the cultivars were generated. Due to this fact, this work aimed to evaluate the behavior of three scallion cultivars in relation to the aspects of productivity, commercial and resistance to pink root.

\section{MATERIAL AND METHODS}

The experiment was carried out from November 10, 2011 to January 30 , 2012, on a farm, with natural history of scallion disease, located in Lontras, Santa Catarina state $\left(27^{\circ} 10^{\prime} \mathrm{S}\right.$, 49³0’ W, altitude 360 meters). The local climate is Cfa type, according to Köppen classification. The experiment was carried out on a soil classified as Cambisol Dystrophic medium texture (Embrapa, 2006). The soil analysis of the experimental field was carried out by the Soil Laboratory of Epagri in Ituporanga; the samples collected at the depth of $20 \mathrm{~cm}$, presented: clay $=$ $38 \%$; $\mathrm{pH}\left(\mathrm{H}_{2} \mathrm{O}\right)=4.6$; $\mathrm{pH}(\mathrm{SMP})=5.4$; organic matter $=2.4 \%$; $\mathrm{P}($ Mehlich 1$)=$ $38.7 \mathrm{mg} \mathrm{dm}^{-3} ; \mathrm{H}+\mathrm{Al}=8.7 \mathrm{cmolc} \mathrm{dm}^{-3}$; $\mathrm{K}=316 \mathrm{mg} \mathrm{dm}^{-3}$; CTC $(\mathrm{pH} \mathrm{7.0})=13.5$ cmolc dm ${ }^{-3} ; \mathrm{Al}=2.6$ cmolc dm$^{-3} ; \mathrm{Ca}=$ 2.7 cmolc dm$^{-3} ; \mathrm{Mg}=1.3$ cmolc dm ${ }^{-3}$.

The seedlings of cultivars Konatsu, Natsu and Nebuka were grown in trays with 128 cells, filled with soil substrate Carolina $^{\circledR}$ constituted by Canadian peat, vermiculite, rice husk. The seeding rate was on average 12 seeds per cell.

The soil correction was adjusted to pH 6.0 with dolomitic limestone, three months before the implementation of the experiment. The basic fertilization was carried out according to Filgueira (2007) recommendation; $30 \mathrm{~kg} \mathrm{ha}{ }^{-1}$ $\mathrm{N}$; $300 \mathrm{~kg} \mathrm{ha}^{-1} \mathrm{P}$ and $120 \mathrm{~kg} \mathrm{ha}^{-1} \mathrm{~K}$ of formulation 5-20-10. At 28 days after sowing, the seedling transplantation was done. The spacing used was of $15 \times 25$ $\mathrm{cm}$, in seedbeds previously prepared, measuring $10 \mathrm{~cm}$ high, $1.0 \mathrm{~m}$ wide and $1.5 \mathrm{~m}$ long. The top dressing with 33.3 $\mathrm{kg} \mathrm{ha} \mathrm{a}^{-1} \mathrm{~N}$, using urea, was performed at 20, 40 and 60 days after the hand weeding of the experiment field. No pests and foliar diseases were observed during the conduction of the experiment and no pesticide was applied.

The treatments consisted of the cultivars Konatsu, Natsu and Nebuka arranged in a randomized block design with four replications. The replications contained 50 plants arranged in five rows of 10 plants.

The harvest was carried out 80 days after the transplantation, when the plants were in an upper stage, higher than $35 \mathrm{~cm}$ (Filgueira, 2007). Ten plants, at random, in each replication were collected and evaluated for the following variables: mean biomass per plant, mean biomass of leaves, average number of leaves, mean length of leaves, mean biomass of marketable leaves, average number of marketable leaves, average number of marketable bunches, mean fresh biomass of roots and average length of root. In the evaluation of marketable productivity, the total number of bunches with $100 \mathrm{~g}$ of mass was determined.

To evaluate the intensity of pink root, a scale, according to Maranhão et al. (2013) was used, in which the level of the disease symptoms ranges from 0 to $5(0=$ roots without symptoms; $1=$ with light pink symptoms; $2=$ with pink symptoms; $3=$ with dark pink symptoms; $4=$ necrotic roots; $5=$ dead roots). After the evaluation using the scale, the level of the symptom was converted to the percentage of severity by Townsend \& Heuberg's (1943) formula described by disease severity $(\%)=\Sigma(\mathrm{n} . \mathrm{v}) / \mathrm{N} . \mathrm{V}$ $\mathrm{x} 100$, where: $\mathrm{n}=$ degree of infection according to the scale; $\mathrm{v}=$ number of roots evaluated per plant; $\mathrm{N}=$ total number of roots evaluated and $\mathrm{V}=$ highest degree infection (5), attributed in the scale proposed by Maranhão et al. (2013).

During the experiment, the monthly rainfall $(\mathrm{mm})$ measured, using a rain gauge installed in the experiment, was of $66 \mathrm{~mm}$ in November, $104 \mathrm{~mm}$ in December and $218 \mathrm{~mm}$ in January.

The data for each variable were subjected to analysis of variance (ANOVA) F-test for the comparison of means by Tukey test at 5\% using the software SASM-Agri (Canteri et al., 2001).

\section{RESULTS AND DISCUSSION}

The cultivar Konatsu showed the highest fresh biomass per plant, higher than $56.11 \%$ and $45.66 \%$ compared to the cultivars Natsu and Nebuka, respectively. Natsu did not differ statistically from Nebuka related to fresh biomass per plant (Table 1). Highest mean fresh biomass of leaves (132.25 $\mathrm{g} \mathrm{plant}^{-1}$ ) was found also for Konatsu, compared to Natsu (59.75 g plant $\left.^{-1}\right)$ and Nebuka (58.25 $\mathrm{g} \mathrm{plant}^{-1}$ ) according to presented in Table 1. The appropriate growth and development of the plants depend on the combination of crop management, environmental factors and genetic potential of the cultivar (Puiatti \& Finger, 2005). As in this work the growing and environmental conditions were similar, the results obtained were directly linked to the genotype, since these conditions are not influenced by 
Table 1. Production of fresh biomass of the entire plant and aerial part of scallion cultivars (produção em biomassa fresca da planta inteira e da parte aérea de cultivares de cebolinhaverde). Lontras, IFC, 2011.

\begin{tabular}{lcccc}
\hline Cultivar & $\begin{array}{c}\text { Biomass } \\
\text { (g/plant) }\end{array}$ & $\begin{array}{c}\text { Foliar biomass } \\
\text { (g/plant) }\end{array}$ & $\begin{array}{c}\text { Leaves } \\
\text { (n\%/plant) }\end{array}$ & $\begin{array}{c}\text { Leaf lenght } \\
\text { (cm) }\end{array}$ \\
\hline Konatsu & $159.50 \mathrm{a}$ & $132.25 \mathrm{a}$ & $35.77 \mathrm{a}$ & $46.35 \mathrm{a}$ \\
Natsu & $89.50 \mathrm{~b}$ & $59.75 \mathrm{~b}$ & $33.67 \mathrm{a}$ & $45.57 \mathrm{ab}$ \\
Nebuka & $72.75 \mathrm{~b}$ & $58.25 \mathrm{~b}$ & $18.60 \mathrm{~b}$ & $41.76 \mathrm{~b}$ \\
\hline CV $(\%)$ & 18.23 & 27.11 & 14.47 & 4.72 \\
\hline
\end{tabular}

Means followed by the same letter, in the same column, did not differ significantly from each other, Tukey, $\mathrm{p}<0,05$ (médias seguidas pela mesma letra, na coluna, não diferem significativamente entre si, Tukey, $5 \%$ ).

Table 2. Commercial production in different cultivars of scallion (produção comercial em diferentes cultivares de cebolinha-verde). Lontras, IFC, 2011.

\begin{tabular}{lccc}
\hline Cultivar & $\begin{array}{c}\text { Marketable leaves } \\
(\mathbf{g} / \mathbf{p l a n t})\end{array}$ & $\begin{array}{c}\text { Marketable leaves } \\
(\mathbf{n} \text { / } / \mathbf{p l a n t})\end{array}$ & $\begin{array}{c}\text { Marketable } \\
\text { bunches }\left(\mathbf{n}^{\mathbf{0}}\right)\end{array}$ \\
\hline Konatsu & $103.25 \mathrm{a}$ & $26.20 \mathrm{a}$ & $11.00 \mathrm{a}$ \\
Natsu & $47.25 \mathrm{~b}$ & $23.87 \mathrm{a}$ & $6.25 \mathrm{~b}$ \\
Nebuka & $45.25 \mathrm{~b}$ & $13.51 \mathrm{~b}$ & $5.75 \mathrm{~b}$ \\
\hline CV $(\%)$ & 26.95 & 13.12 & 22.28 \\
\hline
\end{tabular}

Means followed by the same letter, in the same column, did not differ significantly from each other, Tukey, $\mathrm{p}<0,05$ (médias seguidas pela mesma letra, na coluna, não diferem significativamente entre si, Tukey, $5 \%$ ).

Table 3. Severity of pink-root and fresh biomass of roots of scallion cultivars (severidade de raiz rosada e biomassa fresca de raiz de cultivares de cebolinha-verde). Lontras, IFC, 2011.

\begin{tabular}{lccc}
\hline Cultivar & Pink root (\%)* & $\begin{array}{c}\text { Fresh biomass } \\
\text { of roots (g/plant) }\end{array}$ & $\begin{array}{c}\text { Lenght of roots } \\
(\mathbf{c m})\end{array}$ \\
\hline Konatsu & $70.26 \mathrm{~b}$ & $28.25 \mathrm{a}$ & $12.12^{\mathrm{ns}}$ \\
Natsu & $78.78 \mathrm{a}$ & $22.00 \mathrm{a}$ & 12.00 \\
Nebuka & $80.54 \mathrm{a}$ & $13.75 \mathrm{~b}$ & 12.98 \\
\hline CV $(\%)$ & 2.26 & 14.17 & 9,56 \\
\hline
\end{tabular}

Means followed by the same letter, in the same column, did not differ significantly from each other, Tukey, $\mathrm{p}<0,05$ (médias seguidas pela mesma letra, na coluna, não diferem significativamente entre si, Tukey, $5 \%$ ). *Severity expressed by calculating Heuberg \& Townsend (1943) described by Severity $(\%)=\Sigma(n . v) / N . V \times 100$, where: $n=$ note in the scale; $v=$ number of roots per plant evaluated; $\mathrm{N}=$ total number of roots evaluated and $\mathrm{V}=$ value of the highest score (5) [severidade expressa pelo cálculo de Townsend \& Heuberg (1943) descrita por Severidade $(\%)=\sum$ (n.v) $/$ N.V x 100, onde: $n=$ nota da escala; $\mathrm{v}=\mathrm{n}^{\circ}$ de raízes avaliadas por planta; $\mathrm{N}=\mathrm{n}^{\circ}$ total de raízes avaliadas e $\mathrm{V}=$ valor da maior nota (5)].

genotype $\mathrm{x}$ environment interaction (Squilassi, 2003; Borém, 2013).

The number of leaves in the cultivars Konatsu and Natsu were statistically similar, considering that Konatsu was $52 \%$ superior to Nebuka. The same difference was found in the total length of leaf, in which cultivar Nebuka was lower in $9.9 \%$ compared to Konatsu, which directly reflects the number of bunches produced. Natsu did not differ statistically from Konatsu (Table 1). The marketable leaf biomass (Table 2) in $22.32 \%$, followed by Konatsu (21.92\%) and $20.92 \%$ for Natsu. In relation to marketable bunches, the cultivar Konatsu produced 11 bunches, being higher than $43 \%$, compared to Natsu and $48 \%$ for cultivar Nebuka (Table 2). No statistical difference in the number of bunches was observed between the cultivars Natsu and Nebuka. Heredia et al. (2003) and Heredia \& Vieira (2004) also used the production of bunches as a variable in the evaluation of the productivity of scallion. No significant differences were noticed by $\mathrm{F}$ test among the cultivars for fresh biomass of the roots and root length (Table 3 ).

The cultivar Konatsu differed statistically from the other cultivars, presenting lower disease intensity $(70.26 \%)$. When comparing Konatsu to the other cultivars, it presents $10.81 \%$ and $12.8 \%$ less severity than Natsu and Nebuka, respectively. The percentage of severity between Natsu and Nebuka did not differ statistically (Table 3 ). As the fungus focuses on all stages of plant development, the most characteristic symptom is the pink color, and the evolution of the colors is accompanied by wrinkling of the tissues to the death of the root (Wordell Filho \& Boff, 2006). This process stops the development of the plant. After the death of the root, the plant suffers a reduction in water supply and nutrients which causes a lower vegetative development, which is presupposed to be negatively influencing the total and commercial yield (Tables 1 and 2). This was also verified by Maranhão et al. (2013), who observed reduction of $60 \%$ in the root system in onion by different strains of the pathogen. Despite the high level of severity in the roots, the pathogen is considered weak, since the pink color is due to the diffusion of mycelial pigment in the tissue of infected root and the scaling used may overestimate the severity of the disease. In Brazil, the pathogen is found in all the regions where onion is grown, however direct losses caused by the disease have not been reported yet (Wordell Filho \& Boff, 2006). However, in this study, some evidences that the factor responsible for lower productivity, in scallion, is due to 
the pathogen under study are noticed, since this pathogen directly influenced the production differences among the cultivars evaluated.

According to the results, the cultivar Konatsu showed the highest resistance in the area with the presence of the pathogen providing greater commercial productivity among cultivars of scallion.

\section{REFERENCES}

BORÉM, AL. 2013. Melhoramento de plantas. 6. Ed.rev. e ampl. Viçosa: UFV, 533p.

CANTERI MG; ALTHAUS RA; VIRGENS FILHO JS; GIGLIOTI EA; GODOY CV. 2001. SASM - Agri: Sistema para análise e separação de médias em experimentos agrícolas pelos métodos Scott-Knott, Tukey e Duncan. Revista Brasileira de Agrocomputação 1: 18-24.

COOPERATIVAAGRÍCOLA DE COTIA. 1987. Manual de cultivo das principais hortaliças. Cotia: Cooperativa Central, Departamento de Sementes e Mudas. 104p.

EMBRAPA. 2006. Sistema brasileiro de classificação de solos. 2. Ed. Rio do Janeiro: Embrapa Solos. 306p.

FERREIRA FEP; CASIMIRO MIEC. 2011.
O cultivo da cebolinha gerando renda na Agricultura Familiar de Juazeiro. $3^{\circ}$ Encontro Universitário da UFC no Cariri. Disponível em http://encontros.cariri.ufc.br/index.php/ eu/eu2011/paper/viewFile/.../417. Acessado em 13 de fevereiro de 2013.

FERREIRA ME; CASTELLANE PD; CRUZ MCP. 1993. Nutrição e adubação de hortaliças. In: ANAIS DO SIMPÓSIO SOBRE NUTRIÇÃO E ADUBAÇÃO DE HORTALIÇAS, Jaboticabal. Anais... Piracicaba: POTAFOS. p. 473-476

FILGUEIRA FAR. 2007. Novo manual de olericultura: agrotecnologia moderna na produção e comercialização de hortaliças. 3. Ed.rev. e ampl. Viçosa: UFV. 421p.

HEREDIA ZNA; VIEIRA MC. 2004. Produção e renda bruta da cebolinha solteira e consorciada com espinafre. Horticultura Brasileira 22: 811-814.

HEREDIA ZNA; VIEIRA MC; WEISMANN M; LOURENÇÃO ALF. 2003. Produção e renda bruta de cebolinha e de salsa em cultivo solteiro e consorciado. Horticultura Brasileira 21: 574-577.

LENZ MH. 2005. Viabilidade agroeconômica da produção orgânica de plantas condimentares para o desenvolvimento sustentável em propriedades familiares na Região do Vale do Rio Pardo-RS. Santa Cruz do Sul: Universidade de Santa Cruz do Sul. 100p (Dissertação mestrado).
MAKISHIMA N. 1993. O Cultivo de hortaliças. Brasília: EMPRAPA-CNPH: EMBRAPA-SPI, 116p. (Coleção plantar, 4).

MARANHÃO EHA; NAVAS-CORTÉS JA; JIMÉNEZ-DIAS RM. 2013. Patogenicidade de isolados de Pyrenochaeta terrestris, agente causal da raiz rosada em cebola. Disponível em http://www.abhorticultura. com.br/biblioteca/arquivos/.../olfs4086c.pdf. Acessado em 14 de fevereiro de 2013.

PUIATTI M; FINGER FL. 2005. Fatores climáticos. In: Fontes PCR. Olericultura: teoria e prática. Viçosa: UFV. p.12-17.

SILVA ACF; DELLABRUNA E. 2009. Cultive uma horta e um pomar orgânicos: sementes e mudas para preservar a biodiversidade. Florianópolis: Epagri. 312p.

SQUILASS MG. Interação de genótipos com ambientes. Disponível em http://www.infoteca. cnptia.embrapa.br/bitstream/doc/897925/1/ LivroGXE.pdf. Acessado em 12 de abril de 2014.

TOWNSEND GR; HEUBERGER IN. 1943. Methods for estimating losses caused by diseases in fungicides experiments. Plant Disease Report 27: 340-343.

WORDELL FILHO JA; BOFF P. 2006. Doenças de origem parasitária. In: WORDELL FILHO JA; ROWE E; GONÇALVES PAS; DEBARBA JF; BOFF P; THOMAZELLI LF. Manejo fitossanitário na cultura da cebola. Florianópolis: Epagri. p.19-162. 